\title{
設立30周年記念特集「不動産学の 30 年の成果と将来展望」にあたって Achievement of Real Estate Sciences in the Past 30 Years and the Further Prospects
}

\section{齊藤 広子（明海大学不動産学部 出版編集委員）}

Hiroko SAITO

日本不動産学会は1984年11月に産官学の協力により設立され，今年度30周年を迎えました。

設立の趣旨によりますと,「不動産は国民生活上も国民経済上も極めて大きなウエイトを有し ているが, 不動産に関連する学問の領域を見ると, 法学, 経済学, 経営学, 商学, 建築工学, 土 木工学等既存の学問分野は極めて多岐にわたっており, 単独の学問分野では, 不動産をめぐる諸 問題を十分に理解することは極めて困難である。

しかしながら, わが国における不動産に関する教育研究については, 一部の専門学校等で資格 試験受験用の講座が聞かれ，また，不動産に関連した科目の教育が行われている大学もあり，さ らに，一部の研究機関において部分的な調查研究が行われているが，いずれも部分的なものにと どまっており，不動産に関する総合的な教育・研究は，ほとんど実施されていない現状がある。

他方, アメリカ, イギリス, 韓国, 台湾といった外国においては, 既に相当数の大学等に不動 産に関する学科，コース等が設けられ，充実した内容の教育・研修が実施されている。これらの 国々と比較してわが国の土地, 住宅問題等がより深刻である事実を併せ考えると, わが国におけ る不動産に関する教育研究の現状は, 極めて奇異なものと言え」(不動産関係教育問題検討委員会 不動産に関する教育・研究の整備を目指して 1984年 8 月より), こうした状態から，第一には 不動産に関する総合的な理解・判断能力をもつ人材不足, 第二に不動産に関する諸問題の総合的 な解明の欠如が指摘されていました。

こうした問題のために具体的な対応策として, 第一に大学等での不動産に関する教育体制の整 備, 第二に不動産学の研究分野の確立, 第三に不動産学会の設立が望まれました。当時の大学で は, 不動産学部や不動産学専攻はなく, 私立の 5 大学で不動産の名称がある講義が行われていた だけでした。

30年が経ち, 不動産学会ができ, 不動産学部や不動産学専攻のある大学も生まれました。また, 不動産学会誌にも多くの論文が掲載されてきました。

30年の月日のなかで不動産学はどのように学問として確立したのでしょうか。また, 既存の学 問分野にどれだけの影響を与えたのでしょうか。不動産学は学際的であるとともに, 実践的な学 問として強く求められてきました。そこで, 政策や実務に, そして私たちの国民の生活や経済に どのような影響を与えてきたのでしょうか。

本特集では日本不動産学会設立30周年をひとつの区切りとし, 不動産学が持つ学際性・実践性 に注目し, 学問の広がり, そして実務・政策への影響を検証します。さらには, 今後どのように 展開すべきか。現状を把握し，不動産を取り巻く環境の大きな発展のために将来を展望していき ます。 